\title{
A CRIANÇA PERANTE A ORGANIZAÇÃO SOCIAL AUTORITÁRIA EM A BOLSA AMARELA DE LYGIA BOJUNGA
}

\author{
THE STRANGENESS OF THE CHILD BEFORE THE SOCIAL \\ ORGANIZATION IN LYGIA BOJUNGA'S A BOLSA AMARELA
}

\author{
Poliana Bernabé Leonardeli ${ }^{1}$ \\ [https://orcid.org/0000-0002-5212-5361] \\ DOI: 10.30612/raido.v14i35.11912
}

RESUMO: A proposta do artigo é analisar a percepçăo que a narradora de $A$ Bolsa Amarela, a menina Rachel, possui sobre o meio social em que habita, destacando o estranhamento da criança perante os hábitos e valores dessa sociedade. Bojunga discorre, na obra, acerca de temáticas relacionadas ao mundo da infância como a imaginaçâo, sem perder de vista, no entanto, a relaçăo da infância e suas descobertas com os conflitos gerados pelo contexto social autoritário vigente. Esta temática vai ao encontro de nosso interesse: uma análise mais detida acerca da racionalidade infantil em confronto com a ordem sócio histórica já estabelecida no mundo adulto. Vale destacar, que pelos olhos da narradora, a autora possibilita uma reflexăo acerca dos comportamentos humanos em uma sociedade assentada no autoritarismo, mas também a revisâo de determinados paradigmas e preconceitos por sua obra preservar o pensamento autônomo e independente da protagonista.

Palavras-Chave: Criança; Racionalidade; Enfrentamento

ABSTRACT: The purpose of the article is to analyze the perception of the narrator of A Bolsa Amarela, the girl Rachel, about the social environment in which she lives, highlighting the child's estrangement from the habits and values of this society. Bojunga highlights, in the work, themes related to the world of childhood such as imagination, without losing sight, however, of the relationship of childhood and its phases of discovery with the conflicts generated by the authoritarian social context of the period in which the book was produced. This theme is in our interest: a closer analysis of children's rationality in comparison with the socio-historical order already established in the adult world. It is worth mentioning that, through the eyes of the narrator, the author allows a reflection on human behaviors in a society based on authoritarianism, but also enables the review of certain paradigms and prejudices for preserving autonomous and independent thinking.

Keywords: Child; Rationality; Coping

1 Mestre em Estudos Literários pela Universidade Federal do Espirito Santo. Docente do curso de Pedagogia da Faculdade Municipal de Ensino Superior de Linhares - ES. 


\section{INTRODUÇÃO}

A autora Lygia Bojunga aborda, em sua literatura, a despeito de ser reconhecida como autora infantil e juvenil, temas pertinentes a qualquer idade, escapando a assuntos relacionados tâo somente a um único público, uma vez que sua análise mesmo que subjetiva da realidade vai ao encontro das tensóes e conflitos humanos, sejam estes relacionados a aspectos do psicológico ou a contextos sócio históricos. Apesar de direcionados no mercado a um público juvenil, os livros da autora abordam temas variados como machismo, violência, feminismo, vicio, abandono e tantos outros (SILVA, 2009), muito disso se deve ao fato dela comungar da visăo de muitos escritores do gênero: a de que o leitor nessa fase possui capacidade de reflexáo como qualquer adulto, a diferenciar-se, tăo somente, o uso da linguagem nas obras produzidas para estes grupos. Sobre esse aspecto, Monteiro Lobato afirmava náo haver "fronteiras entre assuntos de crianças e assuntos de adultos" (SANDRONI, 1987, p. 69), e a autora apoia-se nessa mesma visāo.

Além disso, a obra de Lygia Bojunga é substancialmente corajosa e parece dialogar perfeitamente com nosso tempo, faz-se necessária, pode-se dizer, haja vista a visâo reacionária, no campo educacional atual, que pretendem defender como política de estado os representantes da extrema-direita que, por ora, se encontram no poder. A funçâo da literatura é ampla e uma delas é proporcionar ainda mais uma expansâo da consciência e estimular o senso crítico, qualidades fundamentais para o despertar da cidadania, algo que a autora alcança com maestria em sua obra, e recurso fundamental em períodos em que a liberdade passa a ser questionada, como agora.

Nossa escolha para breve reflexăo, neste texto, dentre o rico conjunto de obras publicadas pela autora, será A Bolsa Amarela. Publicado pela primeira vez em 1976, o livro, pela voz da menina Rachel, revela alguns dos conflitos e tensóes sociais de um Brasil assentado nos valores autoritários do sistema vigente até entăo. Conflitos esses que sâo revelados ao longo dos acontecimentos que ocorrem na vida da protagonista e das reflexóes geradas por esses fatos.

Por desnudar sem receios as fraturas de seu tempo e, ao fazê-lo, convidar o leitor a refletir sobre certo saudosismo sem sentido e mal direcionado, que aparece a nos assombrar agora, a obra em questăo e suas temáticas merecem ser postas em discussâo no momento. A destacar, principalmente, o racionalismo, quase solitário em seu meio, da menina Rachel, que ao questionar o absurdo das relaçôes presentes no mundo no qual se encontra, acaba por defrontar-se com uma ordem estabelecida que, apesar de aceita por muitos que ali viviam, se ampara em contradiçōes irreconciliáveis.

\section{LYGIA BOJUNGA; UMA AUTORA ALÉM DOS ESTEREÓTIPOS DO GÊNERO}

Lygia Bojunga nasceu em Pelotas, Rio Grande do Sul e mudou-se aos 8 (oito) anos para o Rio de Janeiro. Em 1951, tornou-se atriz. Após visitar o interior do Brasil em razâo de seu trabalho, resolveu abrir uma escola para crianças pobres, motivada pelo impacto do analfabetismo em nosso território, que encontrou em faixas etárias diversas, nos rincôes do pais. Lançou-se como escritora no ano de 1972 (SILVA, 2009). Da data de lançamento do primeiro livro até os dias atuais, pode-se perceber que alcançou 
uma imensa maturidade literária, sobretudo no que se refere ao uso linguagem e das temáticas abordadas em seus livros.

\begin{abstract}
Por meio da sua narrativa, em que se destaca a linguagem coloquial e a discussăo crítica de problemas da realidade cotidiana, Lygia consegue compreender a mente da criança e do jovem, abordando o real nas suas obras e, ao mesmo tempo, avançando no reino da fantasia, por meio da exploraçáo do maravilhoso, de metáforas e alegorias. (SILVA, 2009, p. 90)
\end{abstract}

Se compararmos a primeira obra de Lygia Bojunga, Os Colegas (1972), e os animais falantes deste livro, mesmo que ali já houvesse uma clara inquietaçăo com o arranjo das coisas, com obras como O Sofá Estampado, de 1980, em cuja temática se aborda a identidade e o luto, perceberemos que a autora "adulteceu" ao longo do tempo, como afirmou Eliana Yunes em uma entrevista em 1996.

Na procura dos aspectos mais maduros da obra de Lygia, que possui elevado renome no campo do gênero infantil e juvenil, tendo sido agraciada inclusive com o prêmio Hans Christian Andersen em 1982, dentre outros, escolheu-se para a análise, neste trabalho, a obra A Bolsa Amarela, escrita em 1976. A temática do livro escolhido vai ao encontro com um aspecto crucial da obra de Lygia Bojunga que se quer explorar neste trabalho: o confronto entre a infância e o mundo adulto autoritário.

Uma das principais problemáticas da autora consiste em analisar a criança acuada dentro do núcleo familiar, o que ocorre em A Bolsa Amarela, obra escolhida para nossa análise, exatamente o livro que recebeu o Prêmio Hans Christian Andersen, em 1982, o prêmio de maior relevo entre o gênero.

Ainda em atividade, a escritora possui hoje sua própria editora, responsável pela produçấo, propaganda e comercializaçăo de sua obra. De certo modo, isso colabora para uma maior independência da autora no mercado editorial (SILVA, 2009). Tal autonomia tem gerado uma literatura ainda mais original e que nos tem deixado como legado um conjunto de livros maduros que servem como norte para a vida adulta, uma vez que sua leitura conduz os pequenos, em meio aos conflitos das escolhas perante o mundo, a uma autonomia libertadora.

Lygia Bojunga tem recebido elogios da crítica especializada, seja brasileira, seja estrangeira. No âmbito brasileiro, foi reportada como a "herdeira ou sucessora de Monteiro Lobato, por estabelecer um espaço em que criança tem - através da liberdade da imaginaçăo - chave para a resoluçăo de conflitos, o que Monteiro Lobato mostrou saber fazer magistralmente" (SILVA, p.153, 2009).

\title{
2 RACHEL, A CRIANÇA SOLITÁRIA EM CONFRONTO COM A IRRACIONALIDADEDO MUNDO ADULTO
}

As personagens dos livros de Lygia Bojunga carecem, logo de início, de identidade pronta, fato que as diferenciam de uma certa tradiçăo pedagógica que marca a literatura para o público juvenil. A conquista dessa identidade é uma tarefa penosa que se efetiva na interaçăo com o contexto social. Esse confronto nunca é tranquilo ou fácil para a personagem. Raquel, a protagonista da história que ora analisamos, por exemplo, "sofre ao se defrontar com as dificuldades impostas pelo esquema dominador do 
mundo dos adultos e busca respostas para os seus questionamentos através do imaginário" (SILVA, p.156, 2009). A literatura juvenil de Lygia Bojunga também realiza uma crítica social por meio de temas complexos, temos, assim, "[...] uma literatura infantil comprometida com a representaçăo realista e às vezes violenta da vida social brasileira. O resultado é um esforço programado de abordar temas até entăo considerados tabus e impróprios para menores." (LAJOLO; ZILBERMAN, 1987, p. 126).

Năo é incomum em meio a essas temáticas, a escolha da autora pela protagonista feminina, a presença da menina como eixo central de uma narrativa é comum em grandes obras literárias. Lewis Carrol legou-nos Alice, que por meio de sua infinita imaginaçăo, questiona a ordem social estabelecida e, assim, constrói uma identidade própria. No Brasil, Monteiro Lobato criou uma Narizinho muito mais vivaz do que qualquer outra personagem do sítio, dela brotavam todas as aventuras fantasiosas do enredo. Acerca da participaçāo da mulher no processo histórico, Karl Marx (1988) já afirmara que quaisquer mudanças na história săo impossíveis sem o fermento feminino. A literatura infantil e juvenil, ao dar espaço ao protagonismo feminino, ajuda a promover mudanças na estrutura patriarcal vigente e proporciona outros olhares a uma dinâmica social estabelecida, como citado por Marx. Lygia Bojunga vai além de Monteiro e Carrol em um sentido, uma vez que ao contrário do que ocorre as outras personagens citadas, Rachel é fruto literário de uma autora, isso dá ao enredo peculiaridades ainda mais interessantes.

A Rachel de Lygia Bojunga é incompreendida pelos mais velhos, principalmente os do núcleo familiar, e ao utilizar a imaginaçăo, cria suas próprias personagens, com quem tece todo o enredo da história, misturando fantasia a realidade, como meio de escapar da crueldade do presente, mas também como subterfugio para reflexăo de si perante o mundo. $\mathrm{O}$ uso da imaginaçáo como recurso, auxilia-a a criar pontes entre os próprios anseios e o contexto que a cerca.

Por ser muito questionadora, sofre bastante quando encara a ordem das coisas, vem disso a necessidade de fuga, mesmo que apenas pelo imaginário. Ela năo entende por que o chefe de família, por exemplo, tem que ser sempre o homem. Mesmo nas brincadeiras, constata que o preconceito aparece e indigna-se: "Se eu quero jogar bola, uma pelada [...] todo mundo diz que é coisa pra homem [...]". (BOJUNGA, 1998, p. 16), o que mostra sua estranheza no que se refere a funçóes sociais determinadas. Por isso, recurso da imaginaçấo como forma de escape.

Logo no primeiro capítulo de A Bolsa Amarela, Rachel prova năo aceitar tais imposiçóes e, assim, insere-se em um espaço ocupado por personagens infantis femininas fortes e criativas, como Alice e Narizinho, faz isso ao demonstrar sua personalidade expansiva, ao afirmar que possui vontades muito fortes, "năo vontades quaisquer como tomar sorvete ou comprar um sapato novo, mas outras, ainda maiores que sempre crescem e engordam" (BOJUNGA, p. 9, 1976) e que, logo de início, indica-se já lhe resultaram em muitos problemas.

Rachel ter tantas vontades, mesmo muito pequena, permite ao leitor uma antevisăo da postura da narradora, ou seja, náo estamos encarando uma personalidade comum que se molda facilmente ao cotidiano, sem reclamar ou pacificamente, mas sim um indivíduo capaz de questionar os absurdos de uma ordem estabelecida sobre égides irreconciliáveis, por que possui uma personalidade criativa e expansiva. Esse tipo de 
comportamento, principalmente em uma menina, aqui pensando na década de 1970, tende a gerar conflitos de inúmeras naturezas, o que ocorre no enredo. Em inúmeras situaçôes Rachel sofre violência simbólica, em alguns momentos beirando a agressâo física das personagens mais próximas, na tentativa de ser exposta e envergonhada pela postura insubmissa. Segundo Marilena Chauí (1985), a açâo violenta objetifica o sujeito, tentando silencia-lo, tornando-o dependente e passivo. Nesse sentido, o ser dominado perde sua autonomia, ou seja, sua liberdade, entendida em Chauí como capacidade de autodeterminaçăo para pensar, querer, sentir e agir.

Na tentativa de escapar de uma realidade que sufocava seus desejos e seus anseios, ainda no primeiro capítulo, observamos a menina tentando criar espaços paralelos de diálogo com um dos primeiros amigos imaginários da obra, André. A criaçâo desse ambiente hipotético de reflexăo por meio de diálogos viria a suprir, em sua vida, o ostracismo a que fora, como criança, relegada. Logo se descobre também que assim agia a fim de escapar dos arroubos autoritários dos familiares, que pouco se importavam com a menina. Nesse sentido, a família repressora de Rachel simboliza o próprio processo histórico vigente no período, pautado no autoritarismo, que cerceava e marginalizava a voz de certo grupo, incluindo-se as crianças e, com mais força ainda, as meninas.

A construçâo da identidade pela personagem precisa ser realizada em meio ao contexto familiar e social que marginaliza a personagem, e isso lhe impóe dificuldades, mas essa temática que permeia todo enredo de A Bolsa Amarela náo será limitada por esse espaço, uma vez que a identidade é o norte de muitas personagens de Lygia Bojunga. Segundo Marisa Lajolo e Regina Zilberman (1987, p. 158):

As personagens dessa autora vivem no limite, crises de identidade: divididas entre a imagem que os outros têm delas e a auto-imagem que irrompe de seu interior, manifestando-se através de desejos, sonhos e viagens, os livros de Lygia Bojunga registram o percurso dos protagonistas em direçấo à posse plena de sua individualidade.

Estudiosos da obra da autora, como as das pesquisadoras citadas, sâo unanimidade ao afirmar que os leitores de Lygia Bojunga amadurecem com a leitura de sua obra, uma vez que na procura que as personagens fazem de si durante o enredo, proporciona-se ao leitor a própria construçáo existencial necessária ao enfrentamento de sua época. Haja vista, "toda arte ser condicionada ao seu tempo e representar a humanidade em consonância com ideias e aspiraçōes, com necessidades e com esperanças de uma situaçăo histórica particular" (ISER, 2002, p . 278). A imagem de Raquel, entăo, resulta na identificaçâo que o leitor infantil terá ao ler a narrativa, pois mostra os pensamentos de uma criança, em sua tentativa de compreender as coisas ao seu redor.

A amizade secreta com André e depois Lorelai, com quem planeja fugir de casa, e a troca de cartas que a menina mantem com eles, servem como escape para Rachel, mas sua atitude logo descoberta pelo irmáo torna-a ainda mais desconfiada dos adultos e de como estes tratavam a criança, uma vez que sua escrita serviu de diversâo para todos da família, inclusive para vizinhos, logo que seu romance inicial foi descoberto, mas escrever, mesmo que escondida, demonstra resiliência e isso significa que a menina nâo desistiu de traçar a própria história, por mais complicado que isso possa parecer:

Qundo eu voltei do cinema encontrei todo mundo rindo da minha história. Era um tal de fazer piada de galo, de galinha, de galinheiro, que năo acabava mais. E o pior 
que eles năo estavam rindo só da história: tavam rindo de mim também, e das coisas que eu pensava (BOJUNGA, 1998, p. 23)

Por serem empobrecidos, os pais de Rachel, pertencentes a uma classe média baixa, trabalhavam fora o dia todo para o sustento de 4 (quatro) filhos. A narradora personagem era a mais nova e sua chegada foi inesperada e mal vista por todos. Rachel até se mostra compadecida com a situaçâo da mâe que trabalha o dia todo e conclui que as mulheres só deveriam se submeter a maternidade quando desejassem (BOJUNGA, 1998, p.24), pensamento que causa discussóes consideráveis mesmo na sociedade atual, mas que foi tratado com naturalidade pela narradora por esta valer-se do racionalismo infantil. Pelos apertos financeiros da família, resultante desta pertencer a um estrato menos favorecido e ter grande prole, pequenos favores de parentes, um pouco mais abastados, chegavam a casa por vezes. Foi por esse caminho que, certo dia, o irmáo de Rachel trouxe para a família um pacote de doaçōes de tia Brunilda.

Em se tratando dessa tia, ela era vista por todos da família com indolência por dela receberem alguns favores ou por ela ocupar uma posiçâo social um pouco mais privilegiada, entretanto Rachel sempre foi muito taxativa: a tia era uma consumista desenfreada que parecia assim agir para escapar do enfrentamento de sua posiçấo social: dona de casa por imposiçấo do marido que assim desejava que fosse. Como forma de se distrair dessa vida que náo lhe agradava ou como modo de torturar Júlio, o marido, por este lhe subjugar a esse destino, tia Brunilda comprava. De tanto comprar e enjoar do que comprou o tempo todo, muito do que ela consumia doava aos parentes de condiçâo social inferior, mas essa doaçăo tinha um preço, que Rachel năo pretendia pagar.

Eu fico boba de ver como a tia Brunilda compra roupa. Compra e enjoa. Enjoa tudo: vestido, bolsa, sapato, blusa. Usa três, quatro vezes e pronto: enjoa. Outro dia eu perguntei:_Se ela enjoa tăo depressa, para que ela compra tanto? E pra poder enjoar mais? Ninguém me deu bola. Fiquei pensando no tio Júlio. Meu pai diz que ele dá um duro danado para ganhar o dinheiro que ele ganha numas coisas que ela enjoa logo, mas ele năo fica (BOJUNGA, p. 25, 1998).

Por esse caminho e em um momento de derrota completa para Rachel, quando suas ideias simbólicas sobre liberdade, contidas em seu romance, passam a ser motivo de piada por todos, e ela como criança năo possui defesa contra tal humilhaçăo, a narradora recebe a bolsa amarela, doada pela tia. As características do objeto coincidem, simbolicamente, com a própria menina, uma vez que a bolsa foi desprezada por todos os irmâos, antes que chegasse as mâos de Rachel, a própria narradora fica surpresa por ter recebido a doaçấo "Ai aconteceu uma coisa diferente: de repente sobrou uma coisa para mim. Era a bolsa. (BOJUNGA, p. 26, 1998)". E Rachel, assim como a bolsa fora, também se sente desprezada por todos de sua família. Interessante perceber que em nenhum momento do enredo percebemos afinidade entre a menina e os pais, uma vez que estes já estavam alienados de suas relaçóes familiares por meio da organizaçăo urbana capitalista, por se encontrarem sempre trabalhando a fim de garantir o sustento, assim como seus dois irmăos mais velhos.

Segundo a teoria marxista, a consequência imediata da alienaçăo do trabalhador, é a alienaçăo do homem pelo homem. Em geral, a proposiçăo de que o homem se tornou estranho ao seu ser, enquanto pertencente a um gênero, significa que um homem permaneceu estranho a outro homem e que, igualmente, cada um deles se tornou estranho 
ao ser do homem, afastando-se de relaçóes cujo caráter sejam mais humanistas. A ausência de um certo calor humano na relaçáo familiar em torno da menina Rachel é latente, a própria Rachel aponta que esse distanciamento dos pais ocorria devido ao "cansaço do trabalho". E as relaçóes mais exploradas, entre ela, irmă e tia, săo marcadas pela violência e poder, comprovando o que a teoria aponta.

Em relaçấo ao presente recebido, a cor da bolsa também resguarda um significado, se em um sentido mais popular, o amarelo significa desprezo, por sua vez, em termos artísticos, essa cor associa-se ao dinamismo e ao despertar da criatividade, também é vista como uma cor que estimula as atividades mentais e o raciocínio. A cor agrada Rachel, segundo ela "Achei isso genial: para mim, amarelo é a cor mais bonita que existe (BOJUNGA, p. 27. 1998)".

Nas páginas que se seguem, a menina descreve pormenores da bolsa, ela se apropria do objeto valorizando-o em cada um dos detalhes que sâo apresentados. $O$ oposto das atitudes da tia com os objetos que adquire, sobre as quais a menina era bem critica. A bolsa passa a ser uma continuidade dela, um espaço de seu inconsciente, um local capaz de guardar três grandes desejos: "ser grande, ser menino e ser escritora", ou seja bolsa será o repositório de todas as fantasias da menina, fantasias estas que, mesmo em meio a estranheza do mundo adulto, irâo conduzi-la para a liberdade e para a autonomia que tanto anseia.

A bolsa amarela tem forte valor simbólico no enredo: guarda dentro de si segredos que podem ser levados por Raquel a qualquer lugar. É um verdadeiro esconderijo para os desejos reprimidos, para as suas vontades. Zilberman e Lygia Cademartori Magalhăes, no livro Literatura infantil: autoritarismo e emancipaçāo (1987, p. 147), afirmam que "a correlaçâo da bolsa com o inconsciente é embasada ainda, pelos atributos de depositária de tudo que é pensado pela menina, por ser levada sempre "a tiracolo" e ser ardorosamente defendida da curiosidade dos demais".

A primeira fantasia a emergir da bolsa será a personagem Afonso, um galo. Ele aparecera em um dos textos escritos pela menina no início do livro. Inclusive, nesses textos, Rachel questionara a relaçăo familiar da qual faz parte comparando-a a uma vida pregressa no campo, quando era possível ser mais livre e as pessoas da família náo estavam ainda com a rotina organizada pelos meios de trabalho, ou seja, agiam coletivamente e possuíam tempo para um ócio diário, o que soa como crítica implícita ao itinerário capitalista burguês, e que ganha relevo ao ser questionado pelo olhar da infância, ou seja, o olhar de quem ainda năo foi tragado totalmente pelo sistema e resguarda consigo capacidade critica perante a realidade, algo que segundo Marx (1985) o capitalismo retira das pessoas.

De acordo com o próprio Afonso, ele fugira do galinheiro para a bolsa amarela por năo querer mais ser galo "tomador-de-conta-de-galinha", papel que lhe fora designado. Afonso fala muito, mais do que a própria narradora. As questǒes pessoais dele também parecem melhores resolvidas do que as de Rachel. Cheio de opiniôes próprias e um tanto quanto racionais, como o fato de que para ele cada galinha toma conta da sua vida, como quando diz a elas "ora, minha filha, o ovo e seu, a vida e sua, resolve como achar melhor" (BOJUNGA, 1998, p. 35), o galo foi julgado e obrigado a fugir do galinheiro dado o perigo de sua visâo subversiva.

Entretanto, a situaçăo de Afonso converge com a de Rachel, também obrigada a ocupar um espaço que lhe foi determinado por diversos fatores como posiçấo social, 
idade e gênero, também ela está em fuga, como o galo, mesmo que pelo caminho do imaginário, mas esse encontro deixa claro que quem comanda esse caminho para a liberdade é a voz dele, que no romance, acaba por empoderar o discurso da narradora.

Muitas possibilidades de reflexăo acerca das relaçôes sócio históricas surgirâo dessa relaçấo entre fantasia e realidade, que ocorre no campo do imaginário entre Rachel e Afonso, o mais comum nas análises lidas é observar que pesquisadores concordam com o fato de que fantasia e realidade năo se excluem, pelo contrário, juntos esses dois recursos se complementam no enfrentamento da ordem e conduzem a personagem para o alcance de sua própria autonomia. E em sua tese de doutorado sobre 0 itinerário Simbólico em Lygia Bojunga, assim Sirlene Cristofano (2010, p.76) se refere ao confronto entre esses dois mundos:

Podemos dizer que a conjunçáo entre fantasia e realidade, contida em A Bolsa Amarela, constrói um mundo coerente, racional, e, simultaneamente, alimenta-se do imaginário. Desta forma, concilia a racionalidade da linguagem com a ficçấo, e, ao mesmo tempo que rege a criaçăo do imaginário năo se afasta do contato com a realidade.

Após o galo acomodar-se na bolsa, temos um retorno ao espaço da realidade e uma referência a uma instituiçấo escolar, quando Rachel cita uma atividade sugerida pela professora: a produçấo de um texto em que ela deveria escrever sobre um presente que gostaria de receber dos pais. Pela escola trabalhar com tempo determinado para a produçăo e por ela possuir excesso criativo, o trabalho năo é encerrado, o fato em si aborda ironicamente o modo como as instituiçóes escolares padronizam as habilidades dos educandos, alinhando-as a necessidades posteriores da produçâo capitalista. Segundo Michel Foucault (2007, p. 47) "todo sistema de educaçăo é uma maneira política de manter ou de modificar a apropriaçấo dos discursos, com os saberes e os poderes que eles trazem consigo".

Importante observar que duas instituiçôes incumbidas pela formaçâo plena da crianças já se encontram amplamente inseridas no modelo capitalista vigente, funcionando de acordo com a lógica desse sistema e em prol dele. A menina, na narrativa, evidencia por descriçóes da rotina que em nenhuma dessas instituiçóes suas necessidades ou habilidades săo encaradas dentro de sua individualidade, pelo contrário, o objetivo sempre parece ser o de moldar Rachel a perspectivas do mercado, a fim de adequá-la a um sistema que năo lhe convém.

Rachel devia estar tăo habituada a essa tentativa de espoliaçăo do próprio discurso, na rotina escolar, que náo se importa muito, pelo contrário, ela ressignifica o que lhe é sugerido pela docente, năo corta o elo com o processo criativo como seria o natural, isso já seria uma reaçáo ao sistema por si só, e, logo, personifica esse guarda-chuva, que agora se torna, em seu imaginário, um presente do galo a ela.

O objeto, agora recebido do galo, tem características muito parecidas com a bolsa, já que está um pouco enguiçado, assim como o fecho da bolsa amarela, parece encontrar-se, no momento, sem funçăo pratica de guarda-chuva, inclusive, mesmo no imaginário, o objeto năo fala, năo responde quando questionado, sua voz encontra-se emperrada, como sua funçăo na realidade. "A chateaçấo aumentou, foi nessa hora que eu resolvi abrir a Guarda-Chuva. Empurrei, empurrei a mola. Mas năo adiantava, a Guarda-Chuva abria um pouquinho e parava no meio do caminho" (BOJUNGA, p. 53, 1998). 
A transformaçăo da menina, ao longo do livro, simboliza-se, também, pelo que ocorre ao Guarda-Chuva, que segundo Afonso possui uma história que se encerrara apenas quando o Guarda-Chuva falar o que poderá ocorrer após um "estalo" (BOJUNGA, 1998), em um sentido simbólico o vocábulo estalo significa "a percepçăo ou compreensăo súbita de algo anteriormente obscuro; luz" (RIOS, 2009, p. 255), ou seja, a menina e o objeto precisam de um momento de epifania, transformador.

Logo adiante, Afonso torna-se praticamente um narrador dentro do enredo, que pertence a Rachel, mas que, nesse instante, parece ser conduzido pelo amigo, que está mais preparado para fazer com que ela alcance o entendimento da situaçấo que enfrenta. Neste momento, surge outra personagem, o primo de Afonso, o galo Terrível, aquele que fora escolhido para galo de briga desde pequenininho. A imagem do galo, tăo presente nesta obra, náo pode ser encarada como aleatória, o galo, segundo a cultura popular, tem um grande valor simbólico, pois significa fé e luz. O cantar do galo a cada manhá representa o triunfo da luz sobre as trevas e do bem acima do mal.

A história do Terrível, na verdade, seria a história de todos os sujeitos em certo grau e circunstância. Ensinado a agir de determinada forma e a cumprir um protocolo comportamental, a ideias e desejos de Terrível (ele se apaixonara por uma franguinha e fugira ao destino) săo cerceados o tempo todo. Em um momento impactante da história é descrito como a cabeça do galo foi aberta e suas vontades costuradas para que ele nunca ansiasse por coisas que năo devia ter e se sujeitasse ao seu destino de galo de briga: “...Bolaram, bolaram, e acabaram resolvendo que o jeito era costurar o pensamento do Terrível e só deixar de fora o pedacinho que pensava: Eu tenho que brigar, eu tenho que ganhar de todo mundo! O resto todo sumia dentro da costura" (BOJUNGA, 1998, p. 95).

Terrível, o galo de briga, tem seu pensamento costurado pelos donos: a única ideia que lhe seria permitida a partir de entăo seria vencer todas as brigas; ele tinha que ganhar de todo mundo. A situaçăo experimentada pelo galo representa a metáfora da intolerância perpetuada pelos adultos, experiência experimentada por Raquel junto a sua família e que considera abominável, porque cruel, e a narrativa evidencia toda essa crueldade pela tortura a que foi submetido o galo Terrível.

O almoço no apartamento da tia a Brunilda, já citada aqui, ocorre no plano da realidade, no enredo, e se interpóe entre a história de Terrível, o que teve os pensamentos costurados. Nesse espaço, se desenrola o acontecimento relatado no capítulo "O almoço", e as tensóes se sobrepóem e se entrecruzam nesse momento. Estar no apartamento com toda família dá a Rachel a sensaçâo de estar como o galo Terrível, como se podada, limitada a um determinado comportamento que lhe aflige profundamente, por que náo o tolera.

Tia Brunilda possui a síndrome do pequeno poder, assim como a irmâ mais velha de Rachel. Ambas as mulheres, submissas cada qual a seu modo: Brunilda ao marido, e a irmă, considerando-se bela, vive a esperar alguém que lhe sustente. Todas as duas humilham Rachel na menor das oportunidades. A Síndrome do pequeno poder, segundo Heleieth Safiotti (2004), é uma atitude de autoritarismo por parte de um indivíduo que, ao receber um poder, usa de forma absoluta e imperativa sem se preocupar com as consequências e problemas periféricos que possa vir a ocasionar. Interessante observar que a violência mais materializada parte de mulheres muito próximas, Simone 
de Beauvoir (1962), afirmou que os opressores nâo teriam tanto poder, se náo fossem apoiados pelos oprimidos, e o posicionamento da irmá de Rachel, assim como o de tia Brunilda nada mais demonstram do que a tentativa de manutençăo de um status quo na condiçấo que assumem.

Durante o encontro familiar na casa de tia Brunilda, ela se vê pressionada pela tia e pelo filho Alberto a determinados comportamentos vexatórios e obrigam-na a abrir a bolsa amarela, a situaçăo metaforiza um jogo de poder que pretende, assim como foi feito ao galo, espoliar a intimidade e os desejos mais profundos da menina, ela nega-se, até que a bolsa explode, devido ter sido espetada pelo Alfinete de Fralda, outra personagem mantida escondida na bolsa: "De repente, deu um estouro danado. Estouro no duro. Parecia até que tinha rebentado uma bomba dentro da bolsa. Todo mundo pulou pra trás [...]". (BOJUNGA, 1998, p. 70).

Essa explosâo causada pelo Alfinete gera, na menina, um impacto que a leva a expressar verdades para a tia que até entăo fora obrigada a esconder, e o faz ao afrontar o primo Alberto e a educaçáo machista que este recebera da tia, o qual era tratado com leniência por todos e podia fazer o que bem quisesse a ela por ser menino, mais velho e de melhor posiçăo social. $\mathrm{O}$ almoço na casa da tia pode ser apontado como o clímax, um momento de tensâo da narrativa, mas esse enfrentamento direto de Rachel ao machismo do tio e aos valores que Brunilda sustenta é também um passo para a própria autonomia da narradora.

Logo após o ocorrido, retornando ao espaço da fantasia, o alfinete sugere à Raquel - para alegria da Guarda-Chuva - um passeio a Casa dos Consertos, onde moravam a menina Lorelai e seus familiares, a qual fora amiga imaginaria de Rachel no início da obra, ocorre aqui um retorno do enredo ao início, como se houvesse uma costura das açôes na trama. A casa com sugestivo nome, era um lugar especial, diferente daquele onde Raquel vivia: todas as funçôes eram democraticamente divididas entre todos. Como dizia Lorelai: "E fica resolvido o que a maioria acha melhor" (BOJUNGA, 1989, p. 100), o que parece ser o mais correto por ser racional de acordo com o pensamento infantil.

O mergulho nesse espaço distópico em A Bolsa Amarela oportuniza a uma outra autora, Eloí Bocheco, a criaçâo de uma obra paralela, A Casa dos Consertos, que dialoga com o romance de Lygia Bojunga, evidenciando a dimensáo desta autora, cuja obra inspira produçôes dentro do sistema literário juvenil. Nesse livro, dona Sofia, uma enfermeira aposentada, abre uma oficina em seu bairro, a fim de consertar brinquedos, mas năo se restringe a isso: ela é uma grande consertadora de almas também. Aos fregueses, ela oferece uma boa prosa e livros, visto que é uma grande leitora das obras literárias e adora conversar com pessoas. Em A Bolsa Amarela, a Casa dos Consertos, faz o mesmo por Rachel, "conserta-lhe o espírito".

A Casa dos Consertos é uma metáfora da transformaçăo, uma vez que, a partir do contato com seus moradores, Raquel resolve assumir seus desejos e liberá-los. Nesse espaço, ela também experimenta uma nova relaçăo com o universo do trabalho, já que ali organizaçăo e respeito mútuo năo se excluem, divergindo da organizaçấo social existente entre as pessoas em sociedade, a qual seus pais e irmáos já eram submetidos. O Alfinete de Fraldas é, portanto, uma metonímia da infância. Encontrado na rua, teme que o considerassem um ser imprestável, mas é ele que indica a Casa dos Consertos 
e espeta as três vontades, que foram infladas pela repressăo. No final da história, é o único que ainda permanece na bolsa amarela (NAVARRO, 2008).

Ao visitar a Casa dos Consertos, Raquel conhece um tipo de organizaçáo social, que lhe parece mais natural, já que neste lugar todos dividem as tarefas e sâo respeitadas pelo que fazem. A visáo da menina, em relaçáo ao mundo que conhecia, passa a ser diferente como ela mesma mostra: "E fiquei achando que a gente grande năo era uma turma tăo difícil de entender que nem eu pensava [...]". (BOJUNGA, 1998, p.101). Foi uma experiência reveladora para si mesma: “De repente, pela primeira vez na vida, achei Raquel um nome legal [...]". (BOJUNGA, 1998, 110).

A partir desse instante, Raquel, entâo, decide ser ela mesma e abandonar suas vontades de ser adulto e de ser menino. Muito por que essas vontades eram canais de escape de uma realidade que ela năo conseguia suportar. Mas decide, também, permanecer com a vontade de escrever. O galo Afonso, por sua vez, vive seu instante de revelaçăo. Ele é um personagem marcado pelo desejo de ter uma ideia e por ela lutar. Afonso é um galo sonhador. Em sua busca, ele percebe que havia muitas pessoas com o pensamento costurado, tal qual seu primo brigâo, que só pensava em ganhar as lutas. O cachorro da Casa dos Consertos, com o pensamento costurado, também só pensava em morder os outros. Finalmente, Afonso teve uma ideia, a de que existem muitas pessoas "com o pensamento costurado", entăo decide: "Vou sair pelo mundo pra năo deixarem costurar pensamento de ninguém [...]". (BOJUNGA, 1998, p. 94).

Posteriormente, já na parte final do romance, no campo da imaginaçâo, Rachel encontra-se na Praia das Pedras, cenário onde comumente havia a briga de galos. A figura do mar é muito marcante na obra de Lygia e representa sempre a redençăo ou a libertaçâo (SILVA, 2009). O próprio Terrível sumira no mar após uma luta. Ali também Raquel se despede de Afonso e da Guarda-Chuva no momento em que o galo resolve sair ao mundo em busca de seus objetivos.

A Guarda-Chuva acompanha o galo. Năo mais sozinho, ele viajará pelo mundo, lutando pelas suas ideias e recomeçará a vida. E em altos brados, como um sonhador, ele grita: "Achei, tá achado, nâo vou mais desachar [...]". (BOJUNGA, 1998, p. 110). Esse é o momento em que cada um vai trilhar seu caminho, tornar-se-âo indivíduos autônomos, pois encontrar-se é desfazer-se das máscaras, como aquelas usadas por Afonso para năo ser reconhecido pelo dono do galinheiro, de onde fugira (NAVARRO, 2008, p.13). Do mesmo modo, Rachel também já năo precisa usar disfarces nas relaçôes sociais que terá pela vida.

Assim, Raquel torna-se aquilo que de fato é: uma menina que gosta de escrever e que enfrentará todas as críticas do mundo adulto para realizar o sonho de viver a vida a seu modo e de escrever seu próprio romance, "[...] a coisa mais inventada do mundo [...]". E feliz consigo mesma conclui: "falaram que tanta coisa era só pra garoto, que eu acabei até pensando que o jeito era nascer garoto. Mas agora eu sei que o jeito é outro [...]" (BOJUNGA, 1998, p. 110). Segundo Foucault (2007, p. 89) : "Devemos nâo somente nos defender, mas também nos afirmar, e nos afirmar náo somente enquanto identidades, mas enquanto força criativa". Rachel enfrentou o mundo a seu modo para sobreviver perante ele, tornando-se a "força criativa" a que o filosofo se refere.

Em uma leitura a partir dos simbolismos que o livro carrega, podemos afirmar que os personagens criados pela menina podem ser relacionados à sua interioridade: o 
Alfinete de fralda, pela pequenez e delicadeza, simboliza a Raquel-criança, a Guardachuva simboliza a Raquel-menina, a que ainda está à procura de sua voz, sua identidade. Os galos associam-se à virilidade, metaforizam a vontade de Raquel de ser menino, mas também săo os recursos narrativos que conduzem a menina ao amanhecer ou ao próprio renascimento. Tudo isso guardado em uma bolsa, que, assim como outros objetos destinados para guardar algo, pode ser associada à simbologia do inconsciente, refletindo, portanto, a interioridade da personagem (SILVA, 1995). Toda essa fantástica simbologia serve de recurso para o enfrentamento da realidade autoritária que cerceia a menina, em um confronto que primeiro ocorre por dentro, para apenas entăo emergir por meio de afirmaçóes que resultam na descoberta de si.

\section{CONSIDERAÇÕES FINAIS}

A ruptura com velhos valores e a renovaçăo pessoal estâo presentes em A Bolsa Amarela, de Lygia Bojunga. No Brasil, a partir de 1970, houve uma produçâo de livros para as crianças, que se voltou para questionamentos dos valores sobre os quais estava assentada a sociedade daquela época. Assim, formou-se uma literatura inquieta que focava as relaçóes entre a criança e o mundo em que ela vivia. Dentre os autores dessa época, Lygia Bojunga se destaca, uma vez que foi apreciada pela sua originalidade de temas e pela capacidade de criar personagens que derrubam valores sócio históricos tradicionais, carregados de preconceitos e tabus.

Além dos temas que aborda - preconceito, família, autoritarismo - a autora também se destaca pela originalidade com que explora as imagens simbólicas presentes na obra. Com o trabalho, mostrou-se a riqueza de abordagem literária que se encerra no interior de A Bolsa Amarela, a partir do enfrentamento de Raquel a imposiçóes sociais autoritárias e a análise do processo de busca de identidade pelo qual passa até sentir-se feliz consigo mesma.

É uma história cujo final năo é relacionado a fatos, năo săo eles que se resolvem no desfecho da narrativa, a vida de Rachel, sua família, enfim, tudo aparenta estar como no início, a mudança está nela e nas percepçōes que agora possui sobre o mundo; há somente a certeza de que a menina aprendeu a conviver com as vontades e amadureceu como pessoa, criando consciência de suas habilidades e náo permitindo que alguém lhe costurasse suas vontades e que estas ficassem reprimidas para sempre. Segundo Hegel (2001) enquanto ser dotado de vontades particulares, os homens vâo superando e suprimindo as necessidades imediatas. Mas o fim de cada açâo particular contém também um objetivo geral, e quando uma açâo se une à outra e a partir de um indivíduo é expressa, carrega em si toda a realizaçáo e transformaçâo necessárias em cada época.

Por isso, faz-se urgente lidar com nossos monstros secretos, nossas feridas clandestinas, nossa insanidade oculta, como dizia Foucault (2009), apenas assim será possível resgatar nossos sonhos, nossa motivaçáo, nossa liberdade. Lygia Bojunga nos conduz junto a Rachel a esse encontro, daí a relevância da leitura e reflexăo dessa obra. 


\section{REFERÊNCIAS}

BOJUNGA, Lygia. A bolsa Amarela. Rio de Janeiro: Agir, 1998.

CHAUÍ, Marilena. "Participando do Debate sobre Mulher e Violência”. In: Franchetto, Bruna, Cavalcanti, Maria Laura V. C. e Heilborn, Maria Luiza (org.). Perspectivas Antropológicas da Mulher 4, Săo Paulo, Zahar Editores, 1985.

CRISTOFANO, S. (2010). Lygia Bojunga e a Literatura Infanto-juvenil: uma Crítica Lúdica e Abordagem à Realidade Social. Linha D'Água, (23), 75-93. https://doi.org/10.11606/ issn.2236-4242.v0i23p75-93

FOUCAULT, Michel. Microfísica do Poder. 24. ed. Săo Paulo: Ediçōes Graal, 2007.

HEGEL G.W.F. "A Razăo na História: Uma Introduçâo Geral à Filosofia da História”. Introdução de HARTMAN, Robert S.; Centauro Ed. SP, 2001.

ISER, Wolfgang (2002). O jogo do texto. In: COSTA LIMA, Luiz. A literatura e o leitor; textos de estética da recepçăo. Rio de Janeiro, Paz e Terra.

MARX, Karl. O Capital. v. 2. 3. ed., São Paulo, Nova Cultural, 1988.

NAVARRO, M.A. Ruptura e renovaçăo em A bolsa amarela, de Lygia Bojunga Nunes. In: II Congresso de Letras do CES/JF, 2008, Juiz de Fora. Caderno de Resumos do II Congresso de Letras do CES/JF. Juiz de Fora: CES/JF, 2008. v. 01.

RIOS, Dermival Ribeiro. Minidicionário Escolar Língua Portuguesa. Săo Paulo: DCL, 2009.

SAFFIOTI, Heleieth I. B. Gênero, patriarcado, violência. Sáo Paulo: Editora Fundaçăo Perseu Abramo, 2004.

SANDRONI, Laura. De Lobato a Bojunga: as reinaçóes renovadas. Rio de Janeiro: Agir, 1987.

SILVA, Vera Maria Tietzmann. O mar na ficçăo de Lygia. In: Seis autores, seis estudos. Goiânia: Ed. UFG, 1995.

VASCONCELOS, Maria Luiza Bretas. Lygia Bojunga Nunes em três tempos: o processo de sua criaçáo. 2001. Dissertação (Mestrado em Literatura) - Universidade Federal de Goiás, Goiânia, 2001.

YUNES, Eliana. Lygia Bojunga ou uma Literatura em processo: uma entrevista com Eliana Yunes. Proleitura, Unesp/UEM/UEL, ano 3, n. 9, fev. 1996.

ZILBERMAN, Regina; MAGALHĀES, Ligia Cademartori. Literatura Infantil: autoritarismo e emancipaçâo. 3. ed. Sâo Paulo: Ática, 1987. 